\title{
Urgensi Kebijakan Pembatasan Sosial Berskala Mikro (PSBM) Pasca Pembatasan Sosial Berskala Besar (PSBB) dalam Penanganan Covid 19 Di Kota Pekanbaru Tahun 2020
}

\author{
Tito Handoko1, Harapan Tua RFS², Zulfa Harirah MS³, Dahlan Tampubolon ${ }^{4}$ \\ 1,3Program Studi Ilmu Pemerintahan, Fakultas Ilmu Sosial dan Ilmu Politik, \\ Universitas Riau, Kota Pekanbaru, Provinsi Riau 28292 \\ 2Program Studi Administrasi Publik, Fakultas Ilmu Sosial dan Ilmu Politik, \\ Universitas Riau, Kota Pekanbaru, Provinsi Riau 28292 \\ 4Program Studi Ekonomi Pembangunan, Fakultas Ekonomi dan Bisnis, \\ Universitas Riau, Kota Pekanbaru, Provinsi Riau 28292
}

Corresponding Author: tito.handoko@lecturer.unri.ac.id

Keyword:

Policies;

Handling;

COVID 19;

Local Goverment

Authority;

Government Actions

\begin{abstract}
After the implementation of Large-Scale Social Restrictions, Pekanbaru City enters the New Normal condition based on the Pekanbaru Mayor Circular regarding the new normal life order. The new life order policyor New Normal actually led to an increase in COVID 19 cases, therefore the Pekanbaru City Government issued a micro-scale social restriction policy, especially in sub-districts that were considered to have the highest rate of spread of COVID 19. This study aims to determine the urgency of micro-scale social restriction policy. The method in this research uses qualitative methods by collecting data sources from legal products, articles and news from the mass media as well as interviews with research sources. The results of this study indicate that the urgency of the presence of this Micro-Scale Social Restriction policy is seen in two ways. First, as an initial step for community habituation in facing the new life order or the new normal. The community is not ready to live in a new normal framework so that less-reaching habituation is needed, namely micro-scale social restrictions. Second, the micro-scale social restriction policy was able to reduce the number of health protocol violations. However, it turns out that the decrease in the number of health protocol violations has no correlation with the decrease in the number of positive COVID cases. For 2 reasons, the implementation of this policy was infact ineffective in suppressing the spread of COVID 19 in Pekanbaru City so that its enforcement was stopped
\end{abstract}

\section{PENDAHULUAN}

Penyebaran Covid 19 nyatanya menimbulkan kepanikan masal baik dari segi sosial, ekonomi dan politik. Dodds (2020) menjelaskan bahwa pandemi merupakan sebuah urgensi bagi kesehatan masyarakat dan diperlukan tindakan politik pemerintah untuk mengatasinya. Pandemi Covid 19 telah menyebar dilebih dari 120 negara di dunia dan telah menginfeksi lebih dari 107.838.255 (https://COVID19.who.int/table). Kondisi ini tentu menyebabkan lumpuhnya berbagai bidang kehidupan, termasuk juga pada skala lokal. Kegiatan perekonomian, pendidikan, ibadah dan lain sebagainya juga terdampak, kondisi ini tentu membutuhkan penanganan serius dari berbagai pihak. Berikut peta penyebaran COVID 19 Dunia (data per September 2020).

Tindakan politik yang hadir untuk mengatasi pandemi ini hampir di berbagai negara adalah pemberlakukan kontrol sosial, karantina penduduk, pengelolaan informasi kesehatan bagi masyarakat. Negara menafsirkan masalah kebijakan kesehatan atas COVID 19 dan kemudian melakukan intervensi kesehatan melalui kepemimpinan 
politik dan medis di ruang lingkup pemerintahan. Negara mempunyai hak dan kewajiban sebagai pengatur dan pengendali kesehatan warga negara dalam suasana kekacauan masa akibat pandemi. Negara mempunyai otoritasnya untuk mengambil segala tindakan untuk mencegah terjadinya lonjakan terhadap penyebaran COVID 19 dan tetap menjaga kestabilan ekonomi. Dengan kata lain, nalar kebijakan Negara dalam mengatasi pandemi COVID 19 di Indonesia akan mempertimbangkan berbagai faktor, termasuk ekonomi (Harirah \& Rizaldi, 2020).

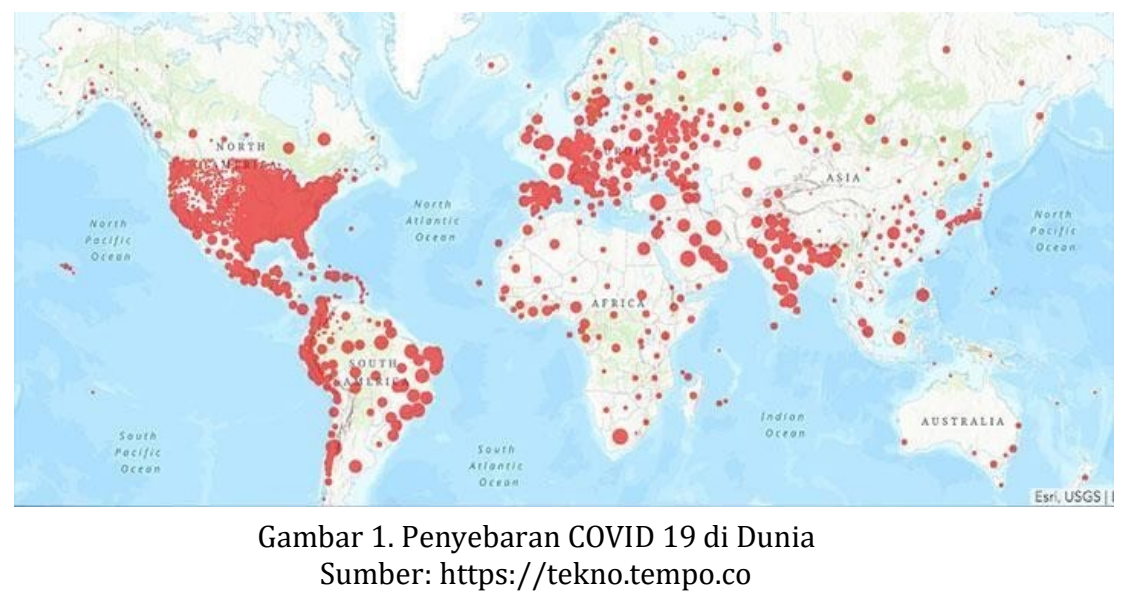

Pada dasarnya, kajian ini dilakukan sebagai bentuk kegelisahan terhadap lemahnya tindakan pemerintah dalam penanganan penyebaran pandemi COVID 19 di Kota Pekanbaru. Sejak meluasnya pandemi COVID 19, Pemerintah Kota Pekanbaru dihadapkan pada persoalan serius terkait tingginya angka penyebaran Covid 19. Penyebaran COVID 19 di Pekanbaru juga sulit terbendung mengingat lambatnya upaya pemerintah dalam menekan penyebaran COVID 19 serta kebijakan dalam skala nasional yang kurang responsif. Oleh sebab itu, penanganan COVID 19 mengalami hambatan dalam pengambilan tindakan pemerintah (Government Action) karena harus melibatkan sikap hukum pemerintah pusat dalam penerbitan kebijakan penanganan dalam skala lokal. Pemerintah tampak tidak memiliki cetak biru (blue print) dalam penanganan penyebaran COVID 19, seluruh tindakan pemerintah didasarkan atas kebijakan pemerintah pusat.

Pasca terbitnya kebijakan Pembatasan Sosial Berskala Besar (PSBB) yang diterbitkan oleh Kementerian Kesehatan, Pemerintah Kota Pekanbaru turut mengambil langkah antisipatif dengan mengajukan status kedaruratan kepada Pemerintah Pusat agar Pekanbaru ditetapkan dalam zona bahaya penanganan COVID 19 sehingga diperlukan pengambilan kebijakan pembatasan sosial berskala besar tersebut. Menurut Bernie (2020) alasan utama ditetapkannya Kota Pekanbaru sebagai salah satu wilayah yang harus menerapkan Pembatasan Sosial Bersekala Besar karena peningkatan penyebaran kasus COVID 19 yang sangat signifikan dan tajam, seperti terlihat pada gambar 1.

Berdasarkan grafik di dibawah ini wilayah kecamatan yang paling signifikan terjadinya peningkatan kasus adalah Kecamatan Tampan, Marpoyan Damai, Tenayan Raya dan Kecamatan Bukit Raya. Peningkatan kasus pada daerah ini karena daerah ini adalah pintu masuk lalu lintas orang dan barang dari dan menuju Kota Pekanbaru, selain itu dengan jumlah penduduk yang padat menyebabkan kecenderungan peningkatan kasus yang signifikan (positivity rate 30,2\%). Tingginya positivity rate Kota Pekanbaru, mengharuskan Pemerintah Kota Pekanbaru menetapkan status kedaruratan penyebaran 
COVID 19, langkah itu didukung pula oleh Gubernur Riau melalui koordinasi vertikal penanganan COVID 19.

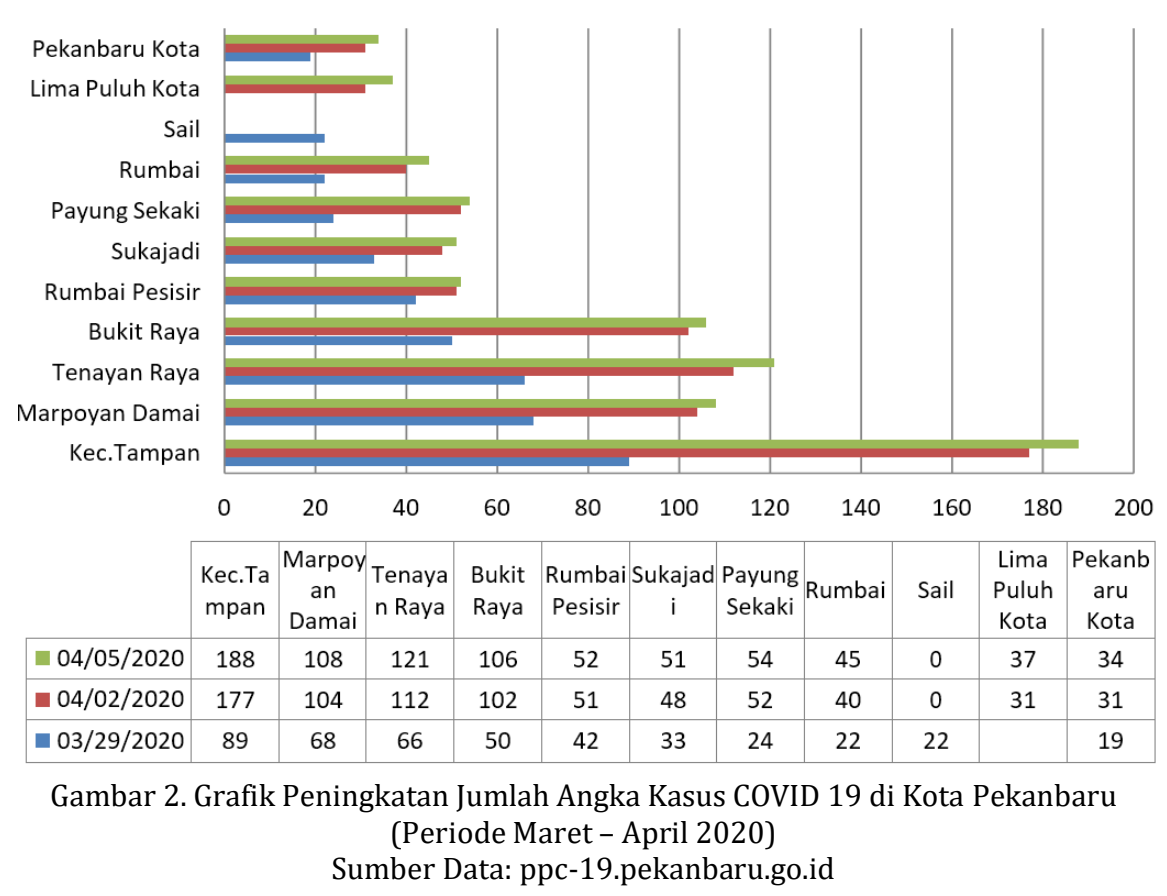

Pada dasarnya, Kota Pekanbaru sebagai ibukota di Provinsi Riau dihadapkan pada dua masalah sekaligus dalam menghadapi penyebaran COVID 19. Pertama, terkait dengan terbatasnya kewenangan pemerintah daerah di sektor kesehatan, hal ini terkait dengan kewenangan pengambilan langkah-langkah strategis dalam penanganan bencana non alam seperti Pandemi COVID 19. Pemerintah Daerah dalam penanganan COVID 19 harus mendapat persetujuan pemerintah pusat dalam menetapkan status kebencanaan akibat pandemi COVID 19. Kedua terkait dengan kemampuan pemerintah daerah menghadapi tekanan pemerintah pusat dan tekanan publik. Hal ini dilihat sebagai konsekuensi regulasi yang tidak menjelaskan secara lengkap terkait dengan kewenangan makro dan mikro Pemda dalam penanganan bencana seperti pandemi COVID 19. Fenomena itu menegaskan bahwa, pelaksanaan prinsip-prinsip desentralisasi dalam hubungan pusat daerah di Indonesia tidak berjalan dengan baik. Pemerintah seperti tidak rela menyerahkan kewenangan urusan wajib itu secara penuh kepada Pemda. Dampaknya, penanganan COVID 19 lambat dan Pemda berada dalam posisi dilema antara mengambil tindakan dan tidak mengambil tindakan.

Upaya nyata menghadapi dilema tersebut adalah dengan menerbitkan kebijakan Pembatasan Sosial Berskala Besar. Berkenaan dengan kebijakan Pembatasan Sosial Berskala Besar di Kota Pekanbaru diberlakukan juga atas dasar keputusan menteri kesehatan yang menyatakan bahwa wilayah Kota Pekanbaru merupakan salah satu penyebaran COVID 19 tertinggi di wilayah Provinsi Riau. Dengan didasarkan keputusan menteri tersebut Pemerintah Kota Pekanbaru mengeluarkan Peraturan Walikota Nomor 74 Tahun 2020 Tentang Pedoman Pelaksanaan Pembatasan Sosial Bersekala Besar Dalam Penanganan Covid 19 di Kota Pekanbaru.

Pemerintah memang telah menyetujui penerapan kebijakan Pembatasan Sosial Berskala Besar (PSBB) di Kota Pekanbaru melalui persetujuan yang dituangkan dalam Keputusan Menteri Kesehatan Nomor HK.01.07/Menkes/250/2020 tentang Penetapan Pembatasan Sosial Berakal Besar di Wilayah Kota Pekan Baru Provinsi Riau dalam 
Rangka Percepatan Corona Disease 2019 (COVID-19). Pelaksanaan PSBB nyatanya mampu menekan penyebaran COVID 19 serta menurunkan positivity rate Pekanbaru menjadi 16,5\%. Namun kebijakan ini juga berdampak pada aspek yang lain terutama dari sisi ekonomi, banyak usaha kecil dan menengah yang bertumbangan (55\%) serta meningkatnya angka pengangguran karena tidak berjalannya aktifitas ekonomi masyarakat dalam skala kecil dan menengah.

Pemberlakukan kebijakan Pembatasan Sosial Bersekala Besar (PSBB) secara spesifik didasarkan pada Peraturan Walikota Pekanbaru Nomor 74 Tahun 2020 Tentang Pedoman Pelaksanaan Pembatasan Sosial Bersekala Besar Dalam Penanganan COVID 19 di Kota Pekanbaru. Isi muatan dari Peraturan Walikota tersebut mengatur tentang panduan pelaksanaan PSBB yaitu membatasi kegiatan pergerakan orang atau barang dalam menekan angka penyebaran COVID 19, meningkatkan antisipasi perkembangan eskalasi penyebaran COVID 19, memperkuat upaya penanganan kesehatan akibat COVID 19 dan menangani dampak ekonomi, sosial dan keamanan dari penyebaran COVID 19.

Pelaksanaan Pembatasan Sosial Bersekala Besar (PSBB) di Kota Pekanbaru dianggap berhasil karena terjadinya angka penurunan yang signifikan pada saat pemberlakukan Pembatasan Sosial Berskala Besar. Pemberlakuan Pembatasan Sosial Berskala Besar tersebut terjadi dalam rentang tiga tahapan yang berdampak pada menurunnya angka penyebaran COVID 19. Dilansir dari media massa bahwa pada pertengahan Bulan Mei disampaikan oleh Tim Gugus Tugas Penanganan COVID 19 Kota Pekanbaru bahwa terjadi angka penurunan yang signifikan yaitu ditandainya dengan tidak adanya angka Pasien Dalam Pengawasan (PDP) (Riauin.com, 2020). Selain itu pemberlakuan Pembatasan Sosial Berskala Besar di Kota Pekanbaru dinilai berdampak atas pemutusan penyebaran COVID 19.

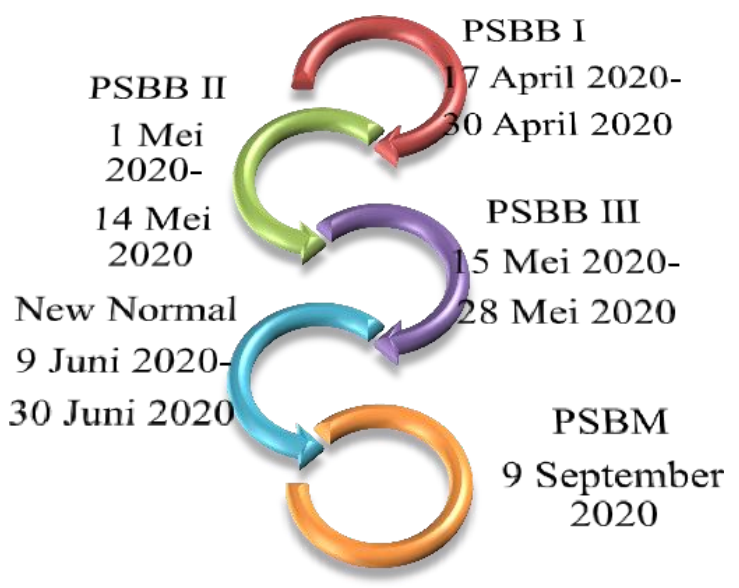

Gambar 3. Sirkulasi Kebijakan Pencegahan COVID 19 di Kota Pekanbaru Sumber Data: Data Olahan, 2020

Pemberlakuan Pembatasan Sosial Bersekala Besar di Kota Pekanbaru dilakukan dalam 3 fase. Pelaksanaan Pembatasan Sosial Berskala Besar di Kota Pekanbaru dilakukan oleh Pemerintah Kota Pekanbaru atas kesepakatan bersama Gubernur Riau, DPRD, MUI, Kepolisian dan TNI dan instansi lainnya (Yudi Walqi Alqatani, 2020). Sedangkan tahap pemberlakuan Pembatasan Sosial Bersekala Besar dilakukan dalam 3 tahap yaitu pada Priode pertama yaitu 30 April 2020, Priode kedua 1 Mei 2020 dan Priode ketiga 17 April 2020 sampai dengan 30 April 2020 yang merupakan perpanjangan ketiga dengan di dasarkan pada Surat Keputusan Walikota Pekanbaru Nomor 375 Tahun 
2020 tentang Perpanjangan Pembatasan Sosial Bersekala Besar Dalam Penanganan COVID 19 di Kota Pekanbaru.

Berdasarkan sirkulasi kebijakan tersebut, Kota Pekanbaru telah melakukan Pembatasan Sosial Berskala Besar sebanyak III periode. Dengan penurunan jumlah positif Covid 19, Pemerintah Kota Pekanbaru mengeluarkan surat keputusan tentang tatanan hidup baru atau New Normal. Tatanan baru itu disebut oleh Walikota Pekanbaru adalah normalisasi kegiatan sektor ekonomi, industri perdagangan dan jasa termasuk juga pertanian dengan tetap menerapkan protokol kesehatan. Akan tetapi berdasarkan surat edaran yang dikeluarkan oleh Walikota Pekanbaru tentang tatanan hidup baru hanya mengatur tentang tatacara kegiatan pelaksanaan ibadah dan tidak mencangkup kehidupan sosial dalam cangkupan luas.

Pasca berakhirnya Pembatasan Sosial Berskala Besar di Kota Pekanbaru, Pemerintah Kota Pekanbaru mengeluarkan kebijakan berkenaan dengan kehidupan normal atau disebut dengan New Normal berdasarkan Surat Edaran Walikota Pekanbaru yaitu Nomor: 451/SE/1024/2020 Tentang Pemberlakuan Perilaku Hidup Baru (New Normal) menuju tatanan kehidupan baru pada penyelenggaraan kegiatan rumah ibadah di tengah pandemi COVID 19. Dalam surat keputusan ini Walikota sebagai Kepala Daerah Kota Pekanbaru hanya menetapkan pola hidup baru dalam rangka penyelenggaraan kegiatan ibadah.

Pemberlakuan New Normal tidak sesuai dengan harapan, terjadi peningkatan penyebaran COVID 19 dan memaksa pemerintah mengambil tindakan spesifik yaitu Pembatasan Sosial Berskala Mikro (PSBM). Kebijakan Pembatasan Sosial Berskala Mikro diterapkan pada beberapa wilayah dengan status positif Covid 19 tertinggi di Kota Pekanbaru. Oleh sebab itu, penelitian ini berhasrat untuk melihat lebih jauh urgensi dari hadirnya kebijakan pembatasan sosial berskala mikro di Kota Pekanbaru. Mengingat penerapan Pembatasan Sosial Berskala Besar (PSBB) telah terbukti nyata berhasil menekan angka penyebaran Covid 19.

\section{METODE PENELITIAN}

Penelitian ini merupakan penelitian kualitatif yang dilakukan untuk mendeskripsikan fenomena yang berkaitan dengan urgensi kebijakan Pembatasan Sosial Berskala Mikro (PSBM) pasca Pembatasan Sosial Bersekala Besar (PSBB) oleh Pemerintah Kota Pekanbaru. Penelitian kualitatif mencakup dua maksud penetapan fokus penelitian. Pertama, penetapan fokus penelitian adalah upaya untuk membatasi studi. Kedua, penetapan fokus berfungsi sebagai kriteria inklusi-ekskluasi, sehingga memudahkan dalam memilah mana data yang sesuai dan mana yang tidak, dengan begitu peneliti tidak dipusingkan dengan datum-datum (meskipun mungkin menarik bagi peneliti) yang terlalu banyak yang pada gilirannya akan mempersulit peneliti sendiri dalam menganalisis data.

Lokasi penelitian ini di Kota Pekanbaru sebagai Ibukota Provinsi Riau yang memiliki tren COVID 19 yang meningkat dari waktu ke waktu. Penelitian ini dilaksanakan selama 6 bulan, yakni April hingga September 2020. Data penelitian ini terdiri dari data primer dan data sekunder. Berikut adalah sumber data dalam penelitian ini yang terdiri dari dua jenis. Pertama, Informan penelitian termasuk kedalam data primer. Data primer adalah data yang diperoleh langsung dari informan penelitian dengan proses wawancara yang dijadikan objek penelitian. Data tersebut diperoleh dari hasil wawancara mendalam dengan informen tersebut. Adapun yang menjadi Informan penelitian ini adalah Pemerintah Kota Pekanbaru, Tim Gugus Tugas Penanggulangan Covid 19, Dinas Kesehatan Kota Pekanbaru, Dinas Sosial Kota Pekanbaru, dan Kepala Badan Penanggulangan Bencana Daerah Kota Pekanbaru. Informan penelitian merupakan 
orang yang menjadi sumber data dalam penelitian.Teknik pemilihan informan dalam penelitian ini yaitu menggunakan teknik purposive. Teknik purposive merupakan teknik mengambilan sumber data dengan pertimbangan tertentu, orang yang dianggap paling tahu tentang permasalahan yang diteliti atau orang yang berkedudukan sebagai penguasa sehingga memudahkan peneliti untuk memahami obyek serta situasi sosial yang diteliti.

Teknik wawancara mendalam dilakukan dengan cara merekam dan membuat informan bersikap lebih terbuka dan leluasa dalam memberi informasi dan data terkait dengan permasalahan penelitian. Sehingga terjadi semacam diskusi dan obrolan santai. Hubungan antara peneliti dengan para informan tidak memiliki jarak agar informan bersikap terbuka dalam menjawab setiap pertanyaan. Walaupun wawancara bersifat terbuka, tetapi peneliti tetap mempersiapkan pertanyaan penting untuk memberi jawaban terkait permasalahan penelitian.

Kedua, dokumen penelitian termasuk kedalam jenis data sekunder. Data sekunder yaitu data yang diperoleh dari lembaga atau instansi yang berwenang, berita dari surat kabar, dan dokumen-dokumen terkait lain. Teknik dokumentasi dilakukan dengan mengumpulkan informasi dari dokumen-dokumen yang ada di Kantor. Meskipun metode wawancara dan observasi menempati posisi dominan dalam penelitian kualitatif, namun metode dokumentasi juga perlu mendapat perhatian dan dimanfaatkan dengan maksimal. Kajian dokumen menjadi sarana pembantu peneliti dalam mengumpulkan data atau informasi dengan membaca surat-surat, pengumuman, ikhtisar rapat, pernyataan tertulis kebijkan tertentu dan tulisan lainnya. Dokumentasi ini berguna untuk mengecek data yang telah terkumpul.

Dalam penelitian kualitatif dikenal istilah keabsahan data, yakni standarisasi derajat kepercayaan atau kebenaran terhadap hasil penelitian sebagaimana syarat setiap penelitian. Penelitian ini mengupayakan keabsahan data melalui teknik triangulasi data. Triangulasi data adalah teknik pemeriksaan keabsahan data yang memanfaatkan sesuatu diluar data itu untuk keperluan pengecekan atau sebagai pembanding terhadap informasi yang diperoleh. Triangulasi melalui sumber berarti membandingkan dan mengecek balik sutau informasi kepada sumber yang berbeda dengan alat dan waktu yang berbeda pula.

Hal terakhir yang dilakukan adalah analisis data terhadap temuan substantif maupun temuan formal. Analisis data menjadi sebuah kegiatan yang dilakukan untuk mengatur,mengurutkan,mengelompokkan, memberi kode/tanda, dan mengkategorikan data sehingga diperoleh temuan yang sesuai dengan masalah yang ingin dijawab. Dalam penelitian kualitatif, analisis merupakan tahap yang memerlukan kreatifitas dan daya intelektual dari peneliti, sebab data yang diperoleh bukan berupa angka-angka, tetapi kata- kata dan tulisan-tulisan. Oleh karena itu, peneliti diharuskan memilih metode yang dirasa cocok dalam melakukan analisis data penelitian agar data tersebut mempunyai makna dan sekaligus dapat menjawab masalah penelitian.

\section{HASIL DAN PEMBAHASAN}

Berdasarkan kajian Greer merekomendasikan bahwa untuk mencegah penyebaran COVID 19 dari segi kebijakan dan politik adalah dengan kebijakan manajemen sosial sebagai pemulihan krisis, baik secara demokrasi maupun otoritas dari pemimpin, penguatan atas kebijakan lembaga politik formal, kapasitas kontrol negara atas kesehatan dan administrasi publik. Kebijakan pemerintah harus lebih memperhatikan politik kesehatan masyarakat untuk mencari solusi atas pemutusan mata rantai penyebaran COVID 19 (Greer et al., 2020). Dalam perspektif kebijakan publik, justru melihat faktor-faktor penyebab kegagalan kebijakan datang dari kapasitas Pemerintah 
Pusat dan Pemerintah Daerah. Segala tindakan dan keputusan pemerintah mesti didasarkan pada peraturan perundang- undangan yang berlaku dan tidak bertentangan dengan kebijakan yang tetinggi. Wadi (2020) menjelaskan bahwa Pemerintahan Daerah dalam penanganan COVID 19 dibatasi ruang geraknya oleh „narasi politik" Pemerintah Pusat.

\section{Kebijakan Pembatasan Sosial Berskala Besar (PSBB) Kota Pekanbaru}

Pembatasan Sosial Berskala Besar (PSBB) adalah salah satu tindakan pemerintah (Government Action) dalam rangka menanggulangi penyebaran COVID 19 (Muh. Hasrul, 2020). Lantika et al (2020) menjelaskan ada beberapa kendala yang terjadi saat penerapan Pembatasan Sosial Berskala Besar di Indonesia. Salah satu permasalahan pelaksanaan dari Pembatasan Sosial Berskala Besar adalah kepastian hukum tentang penetapan kedaruratan kesehatan yang ditetapkan oleh Presiden selaku Kepala Negara. Maksud dari hal ini bahwa Pemerintah harus menjamin kepastian hukum tentang tata cara karantina wilayah. "Lately, Indonesian Government also provided social security program for those affected by COVID 19. The Government released Family Hope Program (Rp. 37.4 trillion), Social Assistance for Staple Food (Rp. 2.2 trillion), Village Fund (Rp. 21 trillion), Cash Labor-Intensive Program (Rp. 16.9 trillion), and Pre-Employment Card Program (Rp.360 billion" (Setyawan \& Lestari, 2020).

Walaupun demikian, Pemerintah Kota Pekanbaru dipandang mampu menekan angka penyebaran COVID 19 dengan mengacu pada kebijakan skala nasional dan penerapan $3 \mathrm{~T}$ (testing, tracing and treatment). Pemerintah Daerah dapat menerapkan kebijakan Pembatasan Sosial Berskala Besar dengan memperhatikan kebijakan nasional yaitu dengan persetujuan Menteri kesehatan. Kumala (2020) menjelaskan bahwa untuk melaksanakan Pembatasan Sosial Berskala Besar Pemerintah Derah harus memenuhi beberapa persyaratan. Persyaratan tersebut ditetapkan berdasarkan Peraturan Menteri Kesehatan Nomor 9 Tahun 2020 tentang Pedoman Pembatasan Sosial Berskala Besar Dalam Rangka Percepatan Penanganan Corona Virus Disease 2019 . Adapun syarat yang harus dipenuhi adalah meningkatnya jumlah kasus atau jumlah kematian secara signifikan di wilayah terindikasi dan adanya hubungan epidemologis dengan wilayah serupa (Cahyandari et al., 2020).

Amrynudin \& Katharin (2020) menjelaskan bahwa perlunya persetujuan Pembatasan Sosial Berskala Besar dari Menteri Kesehatan dipandang sebagai rantai birokrasi yang panjang dan berbelit-belit sehingga menyulitkan Pemerintah daerah untuk mengambil tindakan secara cepat dan akurat. Selain itu permasalahan jarak yang cukup jauh dan dokumen yang menurut daerah cukup banyak menyebabkan sulitnya daerah dalam mengusulkan penetapan kebijakan pembatasan sosial. Pemerintah juga dapat mengambil tindakan baik preventif maupun represif. Upaya preventif tersebut dapat dilihat dari segi produk hukum daerah yang menjadi kewenangan Pemerintah Daerah. Dari segi represif Pemerintah Daerah dapat melakukan penyelarasan peraturan perundang-undangan agar produk hukum daerah tidak bertentangan dengan peraturan perundang-undangan tertinggi, sehingga terdapat kepastian hukum.

Peraturan Pemerintah Republik Indonesia Nomor 21 Tahun 2020 Tentang Pembatasan Sosial Berskala Besar (PSBB) Dalam Rangka Percepatan Penanganan Corona Virus Disease 2019 (Covid 19), Dalam Peraturan Pemerintah ini, yang dimaksud dengan Pembatasan Sosial Berskala Besar (PSBB) adalah pembatasan kegiatan tertentu penduduk dalam suatu wilayah yang diduga terinfeksi Corona Virus Disease 2019 (Covid 91) sedemikian rupa untuk mencegah kemungkinan penyebaran Corona Virus Disease 2019 (Covid I9) Penetapan peraturan tentang adanya PSBB di Indonesia juga merupakan bentuk dari maraknya pasien positif pandemi Covid 19. Berdasarkan Keputusan Presiden 
Republik Indonesia Nomor 11 tahun 2020 Tentang Penetapan Kedaruratan Kesehatan Masyarakat Corona Virus Disease 2019 (Covid 19) memutuskan, Menetapkan Corona Virus Disease 2019 ( Covid 19 ) sebagai jenis penyakit yang menimbulkan Kedaruratan Kesehatan Masyarakat. Menetapkan Kedaruratan Kesehatan Masyarakat Coroana Virus Disease 2019 (Covid 19) di lndonesia yang wajib dilakukan upaya penanggulangan sesuai dengan ketentuan peraturan perundang-undangan. Dalam pasal 13 ayat 1 Peraturan Menteri Kesehatan Nomor 9 Tahun 2020 menjelaskan pelaksanaan sosial berskala besar meliputi ; Peliburan sekolah dan tempat kerja, Pembatasan kegiatan keagamaan, Pembatasan kegiatan ditempat atau fasilitas umum, Pembatasan kegiatan sosial dan budaya, Pembatasan moda transportasi, dan Pembatasan kegiatan lainnya khusus terkait aspek pertahanan dan keamanan.

Dalam mencegah penyebaran COVID 19 Kota Pekanbaru terdapat beberapa penyediaan informasi bagi masyarakat Kota Pekanbaru terkait tenaga kesehatan dan fasilitas kesehatan seperti Rumah Sakit Umum sebagai salah satu bentuk respon Pemerintah Kota Pekanbaru terhadap penyebaran COVID 19 di Kota Pekanbaru. Adapun jumlah tenaga medis di Kota Pekanbaru terlihat pada gambar 3 berikut:

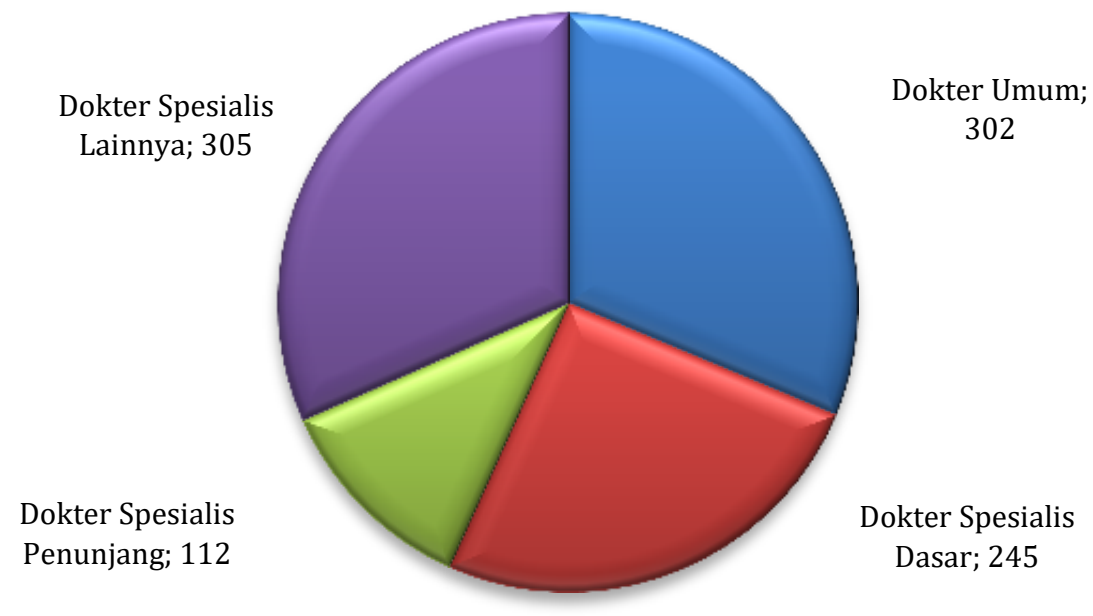

Gambar 3. Jumlah Tenaga Medis Kota Pekanbaru

Sumber Data: (Bppsdmk.kemenkes.go.id, 2020)

Selain fasilitas kesehatan dan tenaga kesehatan Pemerintah memiliki tanggung jawab terhadap pemenuhan kebutuhan belanja baik bagi daerah maupun masyarakat secara tidak langsung. Pemerintah Kota Pekanbaru dalam penyediaan belanja untuk penanganan COVID 19 mempersiapkan anggaran keuangan belanja untuk penanganan COVID 19 sebesar Rp.115.000.000.000. Berdasarkan laporan, 40\% dari anggaran tersebut telah dipergunakan sebesar (Rp.45.080.204.690,-) anggaran tersebut digunakan untuk penanganan COVID 19 yang dinyatakan masuk kedalam anggaran Belanja Tak Terduga (BTT).

\begin{tabular}{|c|c|c|c|}
\hline Realisasi Anggaran & \multicolumn{3}{|c|}{ Jumlah Anggaran } \\
\hline Persiapan Anggaran & & $\mathrm{Rp}$ & 115.000 .000 .000 \\
\hline Anggaran yang digunakan & & $\mathrm{Rp}$ & 45.080 .204 .690 \\
\hline \multicolumn{4}{|c|}{ Pengajuan Pencairan OPD } \\
\hline \multirow[t]{2}{*}{ Dinas Kesehatan } & Priode 1 & $\mathrm{Rp}$ & 3.070 .000 .000 \\
\hline & Priode 2 & $\mathrm{Rp}$ & 8.170 .000 .000 \\
\hline Dinas Perumahan dan Permukiman & & $\mathrm{Rp}$ & 481.000 .000 \\
\hline Dinas Perhubungan & & $\mathrm{Rp}$ & 2.700 .000 .000 \\
\hline
\end{tabular}


Tito Handoko', Harapan Tua RFS', Zulfa Harirah MS', Dahlan Tampubolon 4

\begin{tabular}{|c|c|c|}
\hline Realisasi Anggaran & \multicolumn{2}{|c|}{ Jumlah Anggaran } \\
\hline Dinas Sosial & $\mathrm{Rp}$ & 12.700 .000 .000 \\
\hline Dinas Perdagangan & $\mathrm{Rp}$ & 7.400 .000 .000 \\
\hline $\begin{array}{l}\text { Badan Penanggulangan Bencana } \\
\text { Daerah }\end{array}$ & $\mathrm{Rp}$ & 783.000 .000 \\
\hline
\end{tabular}

Tabel di atas menggambar anggaran yang dipersiapkan oleh Pemerintah Kota Pekanbaru dalam penanganan COVID 19. Alokasi anggaran yang disiapkan pemerintah sebesar 115 Miliar dan anggaran yang telah digunakan untuk belanja pencegahan COVID 19 yaitu sebesar kurang lebih Rp.45 Miliyar. Selain itu terdapat beberapa Organisasi Perangkat Daerah yang mengajukan pencairan anggaran untuk belanja COVID 19 sesuai dengan tugas dan fungsi OPD tersebut seperti Dinas Sosial yang memiliki fungsi dan tugas bagian kesejahteraan masyarakat, Dinas Kesehatan yang memiliki tugas dan fungsi menjamin kesehatan masyarakat diera pandemi COVID 19 sehingga Dinas Kesehatan mengajukan II (Dua) kali pengajuan anggaran belanja. Sementara dalam tahap awal penanganan, Pemko Pekanbaru membentuk Tim Gugus Tugas penanganan COVID 19 yang melibatkan instansi vertikal dan organisasi perangkat daerah (OPD) di lingkungan Pemerintah Kota Pekanbaru.
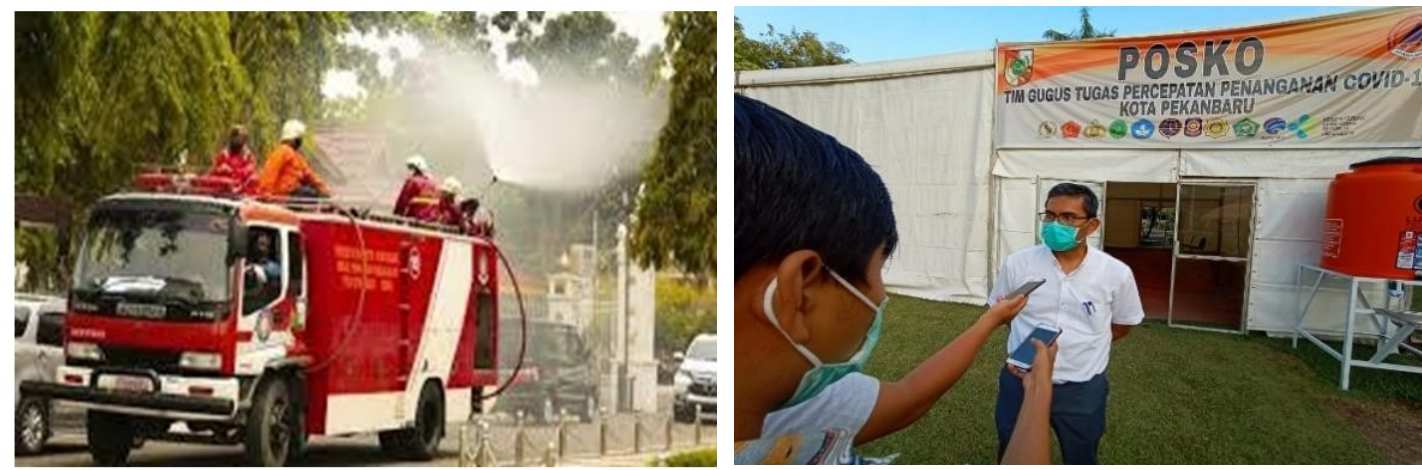

Gambar 4. Penyemprotan Disinfektan dan Pembentukan Posko Tim Gugus Tugas Covid 19 Sumber: Tito dkk, 2020

\section{Kebijakan New Normal dan Peningkatan Positivity Rate}

New Normal atau yang sering dimaknai sebagai tatanan kehidupan baru merupakan konsep yang dicanangkan oleh World Health Organization (WHO) dengan maksud untuk tetap menjalankan aktivitas normal namun dengan ditambah dengan menerapkan protokol kesehatan guna mencegah terjadinya penularan Covid-19. Banyak negara sudah berupaya menerapkan konsep New Normal WHO agar dapat berdampingan dengan virus corona, pilihan ini sejatinya adalah pilihan dilematis negara karena resiko yang ditimbulkan oleh Covid-19 begitu nyata, akan tetapi kehidupan negara harus tetap berlangsung. Kebijakan lockdown atau karantina wilayah nyatanya berdampak pada berbagai aspek kehidupan, selain banyak orang kehilangan pekerjaan dan kesulitan memenuhi kebutuhan sehari-hari, berdiam diri di rumah juga memunculkan dampak psikologis yang tidak kalah berat.

Menurut WHO, konsep New Normal tidak dapat dilakukan begitu saja atau hanya dengan melonggarkan physical distancing. Ada beberapa ketentuan yang disyarakat WHO untuk pelaksanaan New Normal, yaitu negara yang akan menerapkan new normal harus memiliki bukti bahwa penularan Covid-19 di wilayahnya bisa dikendalikan, sistem 
kesehatan yang ada sudah mampu melakukan identifikasi, isolasi, pengujian, pelacakan kontak hingga melakukan karantina orang yang terinfeksi, resiko wabah corona harus ditekan untuk wilayah dengan kerentanan yang tinggi, penerapan new normal di lingkungan kerja ditetapkan langkah-langkah pencegahan sesuai protokol Covid-19, pengendalian resiko kasus dari pembawa virus dan masyarakat harus diberikan kesempatan untuk memberikan pendapat dan dilibatkan dalam proses transisi konsep New Normal.

Tidak dapat dipungkiri, adanya rencana pemerintah menjalankan New Normal di tengah pandemi Covid-19 menuai kritik. Pemerintah dianggap terlalu gegabah meminta masyarakat bersiap menjalankan new normal, sementara kasus Covid-19 terus meningkat. Walaupun masih sebatas konsep, wacana pemberlakuan New Normal oleh banyak pihak dipandang kurang tepat. Pemerintah sendiri menilai bahwa New Normal adalah langkah paling realistis saat ini mengingat tekanan ekonomi negara dan belum adanya kepastian kapan pandemi Covid 19 akan berakhir. Prinsip utama new normal menurut Pemerintah Indonesia adalah menyesuaikan pola hidup. Protokol kesehatan menjadi pedoman baku pelaksanaan New Normal yakni dengan menjaga jarak dan mengurangi kontak fisik dengan orang lain. Pendisiplinan masyarakat untuk patuh terhadap protokol kesehatan menjadi kunci pelaksanaan New Normal, akan tetapi siapa yang dapat menjamin masyarakat akan disiplin?.

Presiden Joko Widodo menyebut New Normal menjadi kondisi yang harus dihadapi masyarakat agar dapat hidup berdampingan atau berdamai dengan Covid-19. Sikap realistis Presiden Joko Widodo ini juga bukan tanpa alasan, tekanan yang dihadapi Pemerintah khususnya soal daya beli menjadi variabel utama kebijakan New Normal. Tekanan ekonomi negara yang hanya tumbuh diangka 2,5\% Per-April 2020 berdampak buruk bagi kelanjutan pembangunan negara dan sendi-sendi ekonomi lainnya. Tentu saja, jika kebijakan ini diimplementasikan akan ada konsekuensi logis yang harus dihadapi oleh Indonesia, konsekuensi terburuk ialah meningkatnya kasus positif Covid19 dan bertambahnya korban jiwa akibat Covid-19. Di sisi lain, pemerintah harus menyelamatkan perekonomian negara.

Konsep New Normal sendiri juga berlaku dengan sangat ketat, Pemerintah Indonesia saat ini juga terus melakukan kajian dan mengembangan sistem scoring atau penilaian tentang tingkat kesiapan terhadap situasi nasional akibat pandemi Covid-19. Mekanisme scoring dilakukan berdasarkan perhitungan edidemologi berbassis RO, kesiapan pemerintah daerah dan kemampuan pelayanan kesehatannya. Skala RO merupakan perhitungan mengenai reproduction rate dari infeksi, reproduction rate ini menghitung fungsi transmisi kontak infeksi berdasarkan waktu. Pemerintah Indonesia membedakan tingkat kesiapan terhadap situasi pandemi ini menjadi lima level yaitu level 1 (masih kritis), level 2 (parah), level 3 (subtansial/ dimulai sebagian), level 4 (moderat) dan level 5 (rendah/ siap semua).

Sedangkan syarat New Normal diterapkan di daerah harus memenuhi 3 indikator yaitu gambaran epidemiologi, suveilans kesehatan masyarakat dan pelayanan kesehatan. Tidak dapat dipungkiri bahwa sistem kesehatan yang ada di Indonesia masih belum memadai, terlebih di daerah. WHO sendiri menyatakan bahwa kesiapan daerah termasuk sistem kesehatannya (Rumah Sakit dan Pelayanannya) adalah syarat mutlak pelaksanaan New Normal. Memang jika disandingkan dengan data sistem kesehatan (kapasitas RS, tenaga medis, anggaran dan daya dukung lainnya) wacana New Normal belum dapat diterapkan sepenuhnya di Indonesia. Gap antara Jawa dan Luar Jawa dalam ketersediaan layanan kesehatan begitu tinggi. Hal ini harus disadari oleh Pemerintah sebagai suatu tantangan pelaksanaan konsep New Normal terlebih kondisi geografis daerah di 
Indonesia juga berbeda-beda dan ini akan menyulitkan distribusi sumber daya dalam penerapan New Normal.

Memang jika kurva epidemiologi saja yang dipakai untuk kebijakan new normal, Pemerintah akan dengan mudah menurunkannya akan tetapi 2 Indikator lain juga tidak kalah penting yaitu surveilans kesehatan masyarakat dan pelayanan kesehatan. Kenaikan iuran BPJS saja pada januari lalu telah berdampak signifikan terhadap kemampuan masyarakat membayar iuran secara mandiri belum lagi jika dibandingkan dengan layanan rumah sakit yang menurut berbagai penelitian kampus begitu diskriminatif antara pasien dengan jaminan layanan kesehatan BPJS dan pasien umum (tanpa BPJS).

Di tengah pandemi Covid-19 ini tentu saja berfikir kritis harus diimbangi dengan solusi konstruktif. Pada bagian akhir tulisan ini, penulis menyampaikan bahwa sudah saatnya bagi pemerintah (pusat dan daerah) untuk membuka mata bahwa sistem kesehatan di Indonesia perlu segera diperbaiki dengan mempersiapkan daerah sebagai garis depan pelayanan kesehatan. Distribusi pengetahuan harus segera dilakukan oleh pemerintah sehingga pusat perkembangan pengetahuan tidak hanya di Jakarta tetapi lebih merata keseluruh wilayah Indonesia. Perlu juga pelonggaran kebijakan rekrutmen sumberdaya khususnya tenaga medis agar daerah dapat secara mandiri memenuhi rasio tenaga medis dengan jumlah penduduk, prasarana kesehatan terutama Fasilitas Kesehatan Tingkat Dasar (Faskesdas) harus lebih di tingkatkan yang saat ini tidak lebih dari hanya sekedar tempat mengurus "Surat Rujukan BPJS".

\section{Kebijakan Pembatasan Sosial Berskala Mikro (PSBM) dan Urgensinya Dalam Penananan COVID 19 di Kota Pekanbaru}

Tidak menjelang lama setelah berlakunya model kebijakan New Normal, Kota Pekanbaru mengalami kesulitan dalam pengendalian angka penyebaran COVID 19 terutama pada rentang September-November 2020. Terjadinya lonjakan angka kasus COVID 19 di Kota Pekanbaru mendorong Pemerintah Kota Pekanbaru untuk berfikir ulang mengenai kebijakan yang mestinya diambil setelah melaksanakan kebijakan Pembatasan Sosial Bersekala Besar selama tiga priode beruntun dan memasuki masa New Normal yang diharapkan akan memperbaiki suasana sosial, ekonomi dan politik di Kota Pekanbaru.

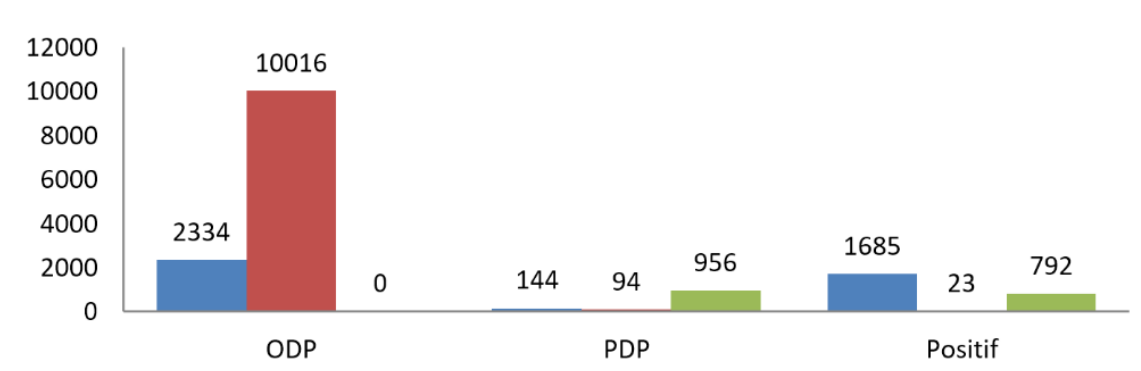

Gambar 5. Kasus COVID 19 di Kota Pekanbaru Pasca Pembatasan Sosial Berskala Besar Sumber: https://ppc-19.pekanbaru.go.id

Grafik di atas menggambarkan angka kasus COVID 19 di Kota Pekanbaru pada bulan September 2020, terdapat 16.044 kasus dengan rincian yaitu Orang Dalam Pemantauan (ODP) dengan angka proses pemantauan 2.334 Orang dan 10.016 selesai dalam pemantauan sehingga total ODP sebanyak 12.350 Orang. Sedangkan kasus Pasien Dalam Pengawasan (PDP) berjumlah 144 Orang dirawat, 94 Orang meninggal, 956 Orang dinyatakan sehat. Berdasarkan catatan tersebut kasus positif COVID 19 tercatat 1.685 Orang dirawat, 23 Orang meninggal dan 792 Orang sembuh, sehingga total positif COVID 
19 sejumlah 2.500 Orang. Berdasarkan infografis di atas bahwa angka kasus COVID 19 di Kota Pekanbaru pada Bulan September meningkat dari angka kasus pasca pelaksanaan Pembatasan Sosial Bersekala Besar dan memasuki era New Normal. Dengan adanya peningkatan jumlah kasus COVID 19 di Kota Pekanbaru pasca dilaksanakannya Pembatasan Sosial Bersekala Besar dan setelah memasuki era New Normal, Pemerintah Provinsi bersama Kepala Daerah Kabupaten/Kota di Riau mengadakan rapat tentang pemberlakuan Pembatasan Sosial Bersekala Mikro (Chaidir Anwar Tanjung, 2020).

Pemberlakuan Pembatasan Sosial Berskala Mikro di Kota Pekanbaru ditetapkan berdasarkan Peraturan Walikota Pekanbaru Nomor 160 Tahun 2020 Tentang Pedoman Pembatasan Sosial Bersekala Mikro Pada Wilayah Kecamatan Tertentu Dalam Upaya Pencegahan dan Pengendalian COVID"19 di Kota Pekanbaru. Pembatasan Sosial Bersekala Mikro adalah pembatasan sosial yang dilakukan di beberapa kecamatan tertentu yang dinyatakan sebagai zona penyebaran COVID 19. (mediacenter.riau.go.id, 2020) awal penerapan Pembatasan Sosial Bersekala Mikro di Kota Pekanbaru untuk awal kali diterapkan di Kecamatan Tampan yang disebut sebagai karantina kewilayahan sekala mikro. Kecamatan Tampan dijadikan sebagai awal wilayah percobaan pelaksanaan Pembatasan Sosial Berskala Mikro diyakini sebagai salah satu wilayah padat penduduk dan penyebaran angka COVID 19 tertinggi.

Pemberlakuan Pembatasan Sosial Berskala Mikro tidak dilakukan diseluruh Kecamatan, akan tetapi dilihat dari angka penyebaran COVID 19 di masing-masing Kecamatan yang diindikasi sebagai wilayah zona merah. Kembali melirik grafik di atas bahwa terdapat beberapa Kecamatan yang dinilai sebagai Kecamatan yang memiliki angka penyebaran COVID 19 tertinggi yaitu Kecamatan Tampan, Kecamatan Tenayan Raya, Kecamatan Bukit Raya dan Kecamatan Marpoyan Damai. Kebijakan Pembatasan Sosial Bersekala Mikro didasarkan atas meningkatnya angka kasus COVID 19 di Kota Pekanbaru setelah pemberlakuan Pembatasan Sosial Bersekala Besar dan memasuki era New Normal. Peningkatan kasus tersebut terjadi dibeberapa wilayah kecamatan di Kota Pekanbaru sehingga Pemerintah Kota Pekanbaru mengambil langkah untuk mengeluarkan kebijakan Pembatasan Sosial Berskala Mikro untuk membatasi pergerakan di skala lokal.

Kebijakan new normal yang diberlakukan setelah kebijakan Pembatasan Sosial berskala Besar dirasa terlalu membebaskan masyarakat. Wajar saja, masyarakat yang selama ini dilarang untuk beraktifitas kemudian menjadi merdeka dengan hadirnya kebijakan new normal. Keadaan ini yang menyebabkan tingkat penularan COVID 19 di Kota Pekanbaru kembali meningkat. Oleh sebab itu, hadirnya kebijakan Pembatasan Sosial Berskala Mikro (PSBM) menjadi pintu masuk penyesuaian masyarakat Kota Pekanbaru menuju tatanan kehidupan baru. PSBM akan menjadi pertimbangan guna menyiapkan adaptasi kebiasaan baru di Kota Pekanbaru.

Pembatasan Sosial Berskala Mikro yang diberlakukan di beberapa Kecamatan di Kota Pekanbaru. Kecamatan Tampan sebagai wilayah pertama yang menerapkan PSBM karena merupakan kecamatan tertinggi kasus COVID 19 Di Pekanbaru. Pada tanggal 3 Oktober 2020, Penerapan PSBM diperluas pada Kecamatan Payung Sekaki, Marpoyan Damai dan Kecamatan Bukit Raya. Perluasan wilayah yang diberlakukan PSBM merupakan hasil evaluasi Satgas Percepatan Penanganan COVID 19 di Kota Pekanbaru. Langkah awal penerapan Pembatasan Sosial Berskala Mikro adalah dilakukan pembatasan kegiatan pada malam hari, yakni pukul 21.00 WIB hingga pukul 07.00 WIB. Dasar hukumnya bersumber dari harmonisasi regulasi PSBM Kementerian Kesehatan dan Kemenpan RB dengan Peraturan Gubernur yang menghasilkan Peraturan Walikota No 160 Tahun 2020 tentang PSBM. 
Pada dasarnya aturan dalam Pembatasan Sosial Berskala Mikro (PSBM) tidak jauh berbeda dengan Pembatasan Sosial Berskala Besar (PSBB). Masyarakat memiliki kewajiban untuk melakukan $4 \mathrm{M}$, yaitu memakai masker, mencuci tangan dengan sabun, menjaga jarak, dan menghindari keramaian. Sedangkan pemerintah, dituntuk untuk melakukan $3 \mathrm{~T}$, yaitu test masyarakat menggunakan swab atau rapid tes, melakukan tracking terhadap pasien positif COVID 19, dan memberikan treatment kepada masyarakat yang membutuhkan perawatan.

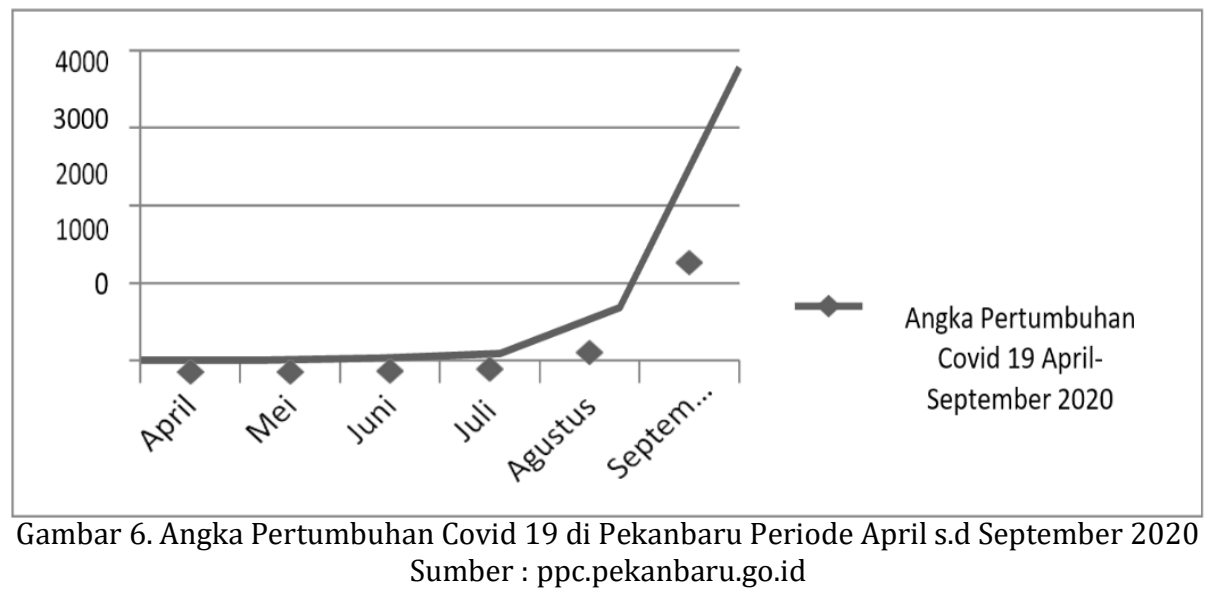

Dalam melaksanakan Pembatasan Sosial Berskala Mikro, Satpol PP Provinsi Riau bekerjasama dengan TNI\& Polri, Satpol PP Kota Pekanbaru, BPBD Kota Pekanbaru, Disperindag Kota Pekanbaru, Satgas kecamatan dan kelurahan untuk melakukan operasi protokol COVID 19 di Kecamatan Marpoyan Damai, Bukit Raya, Payung Sekaki dan Kecamatan Tampan. Operasi Yustisi ini dilakukan dengan memberikan teguran baik berupa teguran lisan, tertulis maupun melakukan kerja sosial di pekarangan kecamatan terhadap orang yang melakukan perkumpulan lebih dari 5 orang, warung kuliner yang tidak taat peraturan PSBM dan mendata masyarakat yang keluar rumah tanpa menggunakan masker. Setelah kebijakan Pembatasan Sosial Berskala Mikro diterapkan di Kecamatan Tampan, angka penambahan kasus positif COVID 19 menurun. PSBM di Kecamatan Tampan dimulai pada tanggal 16 September hlingga 29 September 2020. Tercatat pada tanggal 19 September ada 63 kasus di Kecamatan Tampan dan kemudian menurun menjadi 60 kasus pada tanggal 20 September. Sedangkan pada tanggal 21 September, jumlah penambahan kasus COVID turun menjadi 7 kasus. Pada tanggal setelahnya jumlah kasus COVID 19 mengalami fluktuasi, sehingga PSBM dinilai tidak efektif menekan penyebaran COVID 19.

Pembatasan Sosial Berskala Mikro diterapkan selama 2 minggu yakni sejak tanggal 15 hingga 29 September. Dalam kurun waktu 2 minggu pertama penerapan PSBM, angka lonjakan kasus positif COVID 19 belum dapat ditekan. Oleh sebab itu sejak 30 September 2020 PSBM di Kecamatan Tampan diperpanjang menyusul perluasan PSBM di Kecamatan Bukit Raya, Marpoyan Damai dan Payung Sekaki.Namun setelah perpanjangan waktu penerapan PSBM ini dampaknya dinilai tidak signifikan. Dilihat dari sisi pelanggar protokol kesehatan, masyarakat terbukti lebih disiplin. Hal itu dibuktikan dari jumlah pelanggar protokol kesahatan pada hari pertama sejumlah 146 pelanggar dan pada hari ketujuh hanya

17 orang saja. Keberhasilan ini dianggap sebagai salah satu alasan penting mengapa PSBM perlu dilakukan setelah PSBB Kota Pekanbaru diterapkan. Nyatanya masyarakat Kota Pekanbaru belum siap menerima kebijakan new normal sehingga membutuhkan 
kebijakan pembatasan yang lebih rendah dibandingkan PSBB sebagai media pembiasaan. Meskipun diakui bahwa turunnya tingkat pelanggaran di Kecamatan Tampan ternyata tidak memiliki korelasi dengan turunnya jumlah kasus Positif di Kecamatan, dan itu menunjukkan bahwa kebijakan ini tidak efektif.

Selain sebagai langkah awal pembiasaan masyarakat memasuki era new normal, PSBM dinilai menjadi langkah yang tepat agar dapat fokus menangani COVID 19 pada satu titik utama dalam wilayah yang lebih kecil. PSBM yang diterapkan pada wilayah kecamatan maupun kelurahan dengan tingkat kasus COVID 19 yang tertinggi akan berdampak pada penurunan tingkat penularan di daerah lain secara lebih luas. Intervensi secara lokal ini seharusnya lebih mudah dilakukan sebab mengatur jumlah penduduk yang lebih sedikit, wilayah yang lebih sempit sehingga dianggap lebih efektif dalam menekan angka penularan COVID 19. Meskipun kebijakan PSBM akan memiliki dampak ekonomi, namun itu menjadi konsekuensi kebijakan yang memihak kesehatan

\section{KESIMPULAN}

Pelaksanaan Pembatasan Sosial Bersekala Besar di Kota Pekanbaru dinilai dapat menekan angka penyebaran COVID 19, sehingga Pemerintah Kota Pekanbaru melalui Surat Edaran Walikota Pekanbaru mengeluarkan aturan tentang tatanan hidup baru atau New Normal. Edaran Walikota Pekanbaru tersebut dinilai tidak kuat hukum, karena hanya pengatur tentang tatacara kegiatan di rumah ibadah bukan secara konteks sosial menyeluruh dan tidak ada penegasan hukum. Pemberlakukan New Normal di Kota Pekanbaru tidak berlangsung lama namun dampak terhadap angka kasus COVID 19 di Kota Pekanbaru meningkat tajam. Hal ini mengakibatkan Pemerintah Kota Pekanbaru harus mengambil tindakan hukum yaitu menerbitkan kebijakan Pembatasan Sosial Bersekala Mikro.

Kebijakan tersebut berlaku untuk kecamatan khusus yang dinilai sebagai wilayah padat penduduk dan dengan angka penyebaran COVID 19 tertinggi. Urgensi hadirnya kebijakan Pembatasan Sosial Berskala Mikro ini dilihat dalam dua hal. Pertama, sebagai langkah awal pembiasaan masyarakat dalam menghadapi tatanan kehidupan baru atau new normal. Terbukti pemberlakuan kebijakan new normal setelah dilakukannya Pembatasan Sosial Berskala Besar justru meningkatkan jumlah kasus COVID 19 di Kota Pekanbaru secara siginifikan. Hal ini menyiratkan bahwa masyarakat belum siap hidup dalam kerangka new normal sehingga dibutuhkan pembiasaan yang lebih rendah jangkauannya, yakni pembatasan sosial berskala mikro. Kedua, Kebijakan pembatasan sosial berskala mikro mampu menekan kembali angka kasus COVID 19 di 4 kecamatan menjadi lebih rendah dari sebelum PSBM diterapkan. Dilihat dari jumlah pelanggar protokol kesehatan juga mengalami penurunan. Artinya masyarakat dinilai sudah mulai disiplin menegakkan protokol kesehatan pada saat keluar rumah

\section{DAFTAR PUSTAKA}

Adawiyah, DP. R., \& Sholichati, I. (2020). Kebijakan PSBB Pemerintah Kota Surabaya dalam The PSBB Policy of Surabaya Goverment in Preventing the Spread of COVID 19 Virus. Journal of Islamic Communication, 3(1).

Adlin, A., \& Yusri, A. (2020). Penegakan Hukum Pemerintahan : Kekuasaan Walikota Pekanbaru Memberlakukan Beleidsregels Guna Memutus Penyebaran Virus COVID 19 Di Kota Pekanbaru. Jurnal Ilmiah Muqoddimah: Jurnal Ilmu Sosial, Politik Dan Hummanioramaniora, 4(2), 71. https://doi.org/10.31604/jim.v4i2.2020.71-81

Agustino, L. (2020). Analisis Kebijakan Penanganan Wabah COVID 19: Pengalaman Indonesia Analysis Of COVID 19 Outbreak Handling Policy: The Experience Of Indonesia. Junal Borneo Administrator, 16(2), 253-270. 
Alqatani, W.Y (2020). Perpanjang PSBB di Pekanbaru Sampai 14 Mei Didukung Semua Pihak. Celotehriau.Com.

Amrynudin, A. D. K., \& Katharin, R. (2020). Birokrasi Dan Kebijakan Percepatan Penanganan COVID 19. Puslit BKD, XII(9), 25-30.

Berita Pemko. (2020). Kenapa Pekanbaru New Normal? Ini Penjelasan Walikota. Pekanbaru.Go.Id. https://pekanbaru.go.id/news/kenapa-pekanbaru-new-normalini- penjelasan-walikota.com Diakses pada 3 Juli 2020

Betuah.com. (2020). Sebaran Corona Meningkat, Pekanbaru Masih Kaji Penerapan PSBB. Betuah.Com. https://betuah.com/mobile/detail/2900/sebaran-coronameningkat-pekanbaru-masih-kaji-penerapan-psbb.com Diakses pada 28 Mei 2020 Bppsdmk.kemenkes.go.id. (2020). Data Tenaga Medis di Rumah Saki Kota Pekanbaru, Provinsi Riau. Bppsdmk.Kemenkes.Go.Id. Diakses pada 28 Mei 2020

Cahyandari, D., Hadiyantina, S., Ramadhan, N., Hukum, F., \& Brawijaya, U. (2020). Upaya Pemerintah Daerah dalam Pencegahan dan Penanggulangan Wabah Virus Korona. Cakrawala: Jurnal Litbang Kebijakan, 14, 76-81. https://doi.org/10.32781/cakrawala.v14i1.332

Chaidir Anwar Tanjung. (2020). Tambah 134, Kasus COVID'19 di Pekanbaru Tembus 2.717 per 7 September. Detiknews.Com. https://news.detik.com/berita/tambah134-kasus- COVID 19-di-pekanbaru-tembus-2717-per-7-september.com

CNNIndonesia. (2020). PSBB Pekanbaru Disetujui Karena Jadi Episentrum Corona Riau. CNNIndonesia. https://m.cnnindonesia.com/nasional/psbb-pekanbaru-disetujuikarena-jadi-episentrum-corona-riau. Diakses pada 18 Juli 2020

Dodds, K., Broto, V. C., Detterbeck, K., Jones, M., Mamadouh, V., Ramutsindela, M., Varsanyi, M., Wachsmuth, D., \& Woon, C. Y. (2020). The COVID 19 pandemic: territorial, political and governance dimensions of the crisis. Territory, Politics, Governance, 8(3), 289-298. https://doi.org/10.1080/21622671.2020.1771022

Greer, S. L., King, E. J., da Fonseca, E. M., \& Peralta-Santos, A. (2020). The comparative politics of COVID 19: The need to understand government responses. Global Public Health, 15(9), 1413-1416. https://doi.org/10.1080/17441692.2020.1783340

Hairi, P. J. (2020). Implikasi Hukum Pembatasan Sosial Berskala Besar Terkait Pencegahan COVID 19. Info Singkat Bidang Hukum, 12(April), 1-6.

Hamid, A. R. A. H. (2020). Social responsibility of medical journal: A concern for COVID 19 pandemic. Medical Journal of Indonesia, 29(1), 1-3. https://doi.org/10.13181/mji.ed.204629

Harirah, Z., \& Rizaldi, A. (2020). Merespon Nalar Kebijakan Negara dalam Menangani Pandemi COVID 19 di Indonesia. Jurnal Ekonomi dan Kebijakan Publik Indonesia Vol 7 No 1 DOI: https://doi.org/10.24815/ekapi.v7i1.17370

Herdiana, D. (2020). Social Distancing : Indonesian Policy Response to the Corona Virus Jurnal Ilmu Administrasi, 17(1), 93-110.

Intisari, K., Dan, P., Tentang, P., Corona, P., Kebijakan, T., Negara, K., Stabilitas, D. A. N., Keuangan, S., Rangka, D., Ancaman, M., Membahayakan, Y., Kesehatan, K., Corona, M., Disease, V., Anggaran, R., Pengadaan, S., Dan, B., Dalam, J., Antiseptik, S. E., ... Tugas, G. (n.d.). No Title.

Joseph Ginting. (2020). Pasien COVID 19 Melonjak Di Era New Normal, Hamdan Jumpai Walikota. Www.Riauonline.Co.Id.

https://www.riauonline.co.id.riau/kota-pekanbaru/read/2020/07/06/pasienCOVID 19-melonjak-di-era-new-normal-hamdani- jumapi-wali-kota.com

Kumala, R. D. M. (2020). Legal Analysis of Government Policy on Large Scale Social Restriction in Handling COVID19. The Indonesian Journal of International Clinical Legal Education, 2(May), 181-200. https://doi.org/10.15294/ijicle.v2i2.38326 
Lantika, P., Permadhi, O., Hukum, F., \& Mahasaraswati, U. (2020). problematika penerapan sistem karantina wilayah dan psbb dalam penanggulangan covid 19 . Jurnal Kertha Semaya, 8(9), 1355-1365.

Lin, Q., Zhao, S., Gao, D., Lou, Y., Yang, S., Musa, S. S., Wang, M. H., Cai, Y., Wang, W., Yang, L., \& He, D. (2020). A conceptual model for the coronavirus disease 2019 (COVID 19) outbreak in Wuhan, China with individual reaction and governmental action. International Journal of Infectious Diseases, 93, 211-216. https://doi.org/10.1016/j.ijid.2020.02.058

Mediacenter.riau.go.id. (2020). Mulai Kamis, Pekanbaru Terapkan PSBM di Kecamatan Tampan.

Mediacenter.Riau.Go.Id. https://mediacenter.riau.go.id/read/57022/mulai-kamis-pekanbaru-terapkanpsbm-di-kecamatan.com Diakses pada 21 Agustus 2020

Muh. Hasrul. (2020). Aspek Hukum Pemberlakuan Pembatasan Sosial Berskala Besar (Psbb) Dalam Rangka Penanganan Corona Virus Disease 2019 (Covid 19) Muh. Legislatif, 3(1), 385-398.

Muhammad Bernie. (2020). Menkes Terawan Tetapkan PSBB Kota Pekanbaru Riau. Tirto.Id. $\quad$ https://tirto.id/menkes-terawan-tetapkan-psbb-kota-pekanbaruriau.com Diakses pada 17 Juni 2020

Muhyiddin. (2020). COVID 19, New Normal, dan Perencanaan Pembangunan di Indonesia. Jurnal Perencanaan Pembangunan: The Indonesian Journal of Development Planning, 4(2), 240-252. https://doi.org/10.36574/ipp.v4i2.118

Nasruddin, R., \& Haq, I. (2020). Pembatasan Sosial Berskala Besar (PSBB) dan Masyarakat Berpenghasilan Rendah. SALAM: Jurnal Sosial Dan Budaya Syar-I, 7(7). https://doi.org/10.15408/sjsbs.v7i7.15569

Novanda, G. D. (2020). C Urrent C Ommentary a Dvocacy and L Egal a Id D Uring C Ovid19 P Andemic : H Ow I Ndonesia S Urvives? The Indonesian Journal of International Clinical Legal Education, 2(2), 101-110. https://doi.org/10.15294/ijicle.v2i2.38331

Radarbisnis.co.id. (2020). Anggaran Penanganan COVID 19 di Pekanbaru Sudah Terpakai Rp45M.

Radarbisnis.Co.Id.

https://radarbisnis.co.id/mobile/detailberita/7055/anggaran-penanganan-

COVID19-di-pekanbaru-sudah-terpakai-rp-45-m.com Diakses pada 8 Agustus 2020

Riauin.com. (2020). PSBB Dinilai Perlambat Penyebaran Virus Corona di Pekanbaru.

Riauin.Com. https://www.riauin.com/psbb-dinilai-perlambat-penyebaran-viruscorona- di-pekanbaru.com Diakses pada 2 Juli 2020

Setiabudy, R. (2020). Research ethics in COVID 19 pandemic. From Medical Journal of Indonesia;, 2, 113-114. https://doi.org/https://doi.org/10.13181/mji.ed.204648 Med Setyawan, F. E. B., \& Lestari, R. (2020). Challenges of Stay-At-Home Policy Implementation During the Coronavirus (COVID 19) Pandemic in Indonesia. Jurnal $\begin{array}{llll}\text { Administrasi } \quad \text { Kesehatan } & \text { Indonesia, }\end{array}$ https://doi.org/10.20473/jaki.v8i2.2020.15-20

Telaumbanua, D. (2020). Urgensi Pembentukan Aturan Terkait Pencegahan COVID 19 di Indonesia. QALAMUNA: Jurnal Pendidikan, Sosial, Dan Agama, 12(01), 59-70. https://doi.org/10.37680/qalamuna.v12i01.290

Wadi, R. (2020). Konstitusionalitas Pemerintah Daerah dalam Menetapkan Kebijakan Lockdown pada Penananganan COVID 19. SALAM: Jurnal Sosial Dan Budaya Syar-I, 7(5). https://doi.org/10.15408/sjsbs.v7i5.15319

Yudha Manggala P Putra. (2020). Riau Dorong PSBB di Pekanbaru. Republik.Co.Id. https://republika.co.id/riau-dorong-psbb-di-pekanbaru.com Diakses tanggal 26 Juni 2020 